\title{
A LINGUAGEM RETÓRICA DA PROPAGANDA: UMA ANÁLISE COMPARATIVA
}

\author{
THE ADVERTISING RHETORICAL LANGUAGE: \\ ACOMPARATIVE ANALYSIS.
}

GoIAMÉRICo Felício CARNeIRo dos SANTOS

Graduação em Letras (1997) pela Universidade Católica de Goiás. Mestrado em

Estudos da linguagem-Teoria da Literatura, pela Universidade Federal de Goiás (1999). Dissertação: A cena da culpa: tentativas de parricídio na história da literatura; Doutor em Teoria da Literatura, pela PUC-Rio, Tese: Angústias da influência: parricídio e história da literatura, parcialmente publicada em livro pela Secretaria Municipal de Cultura (2005).

Nellie Rego SANtee

Bacharelado em Comunicação Social, Habilitação em Publicidade e Propaganda, mestranda: Pós-Graduação em Comunicação, Universidade Federal de Goiás.

\section{RESUMO}

A retórica vem sendo utilizada como uma ferramenta persuasiva desde os tempos da Grécia Antiga, e nos séc. XX e XXI ela tem retomado sua força com a massificação dos meios de comunicação e a utilização dos mesmos para a divulgação de produtos, serviços e marcas pela propaganda e publicidade. Este estudo tem como objetivo aprofundar o estudo das relações que podem ser feitas entre a linguagem da propaganda e o sistema retórico desenvolvido por Aristóteles, passando por todas as suas etapas: Invenção, Disposição, Elocução e Ação. Foi abordada também a maneira como a propaganda se utiliza dos argumentos e do estilo para alcançar a persuasão, além da relação do texto publicitário com o etos, patos e logos, para concluir que a propaganda, como um texto persuasivo por essência, se utiliza muito mais da retórica do que imaginam os criativos que a produzem.

Palavras-chave: Publicidade. Propaganda. Retórica. Aristóteles. Linguagem publicitária. Sistema retórico. Persuasão.

\section{ABSTRACT}

The rhetoric has been used as a persuasive tool since the Ancient Greece, and now, in the XX and XXI centuries, it has returned along with the mass media and their use for advertising brands and products. This article seeks to understand the relations between the advertising language and the rhetorical system developed by Aristotle, going through all their stages: Invention (heurésis), Disposition (taxis), Elocution (lexis), Action (hypocrisis). It will also be said how advertising uses rhetorical arguments and style to pursue persuasion, along 
with the relation between the ad text and etos, patos and logos, to finally see that advertising, as a persuasive discourse by essence, uses a lot much more from rhetoric that their creative people imagine.

Key words: Advertising. Rhetoric. Aristotle. Advertising language. Rhetorical system. Persuasion.

\section{A linguagem retórica da propaganda: Uma análise comparativa.}

Retórica, a arte persuasiva.

A retórica, desde os tempos de Aristóteles com sua obra a "Arte Retórica", vem sendo utilizada como uma ferramenta persuasiva na comunicação, seja ela oral ou escrita. A partir do século $\mathrm{XX}$, com a modernização dos meios de comunicação e a utilização dos mesmos para a veiculação de anúncios de propaganda, o uso da retórica cresceu ainda mais. Conforme Reboul (2004, p. 25), a palavra é a arma mais eficaz, pois só ela é capaz de definir o justo e o injusto, o útil e o nocivo, o nobre e o desprezível: "A retórica, arte ou técnica da palavra, é, portanto, indispensável". Para qualquer texto que vise à persuasão ou ao debate, o uso da retórica se torna necessário, e a propaganda, como um texto persuasivo por natureza, se utiliza da retórica em sua construção, mesmo que não haja o conhecimento de seu criador. Deste modo, eis a definição proposta por Reboul (2004, p. XIV): "[...] retórica é a arte de persuadir pelo discurso". A respeito do discurso, Aristóteles ([1972?], Arte Retórica, I, II, II, 6, p. 35) diz: "Enfim, é pelo discurso que persuadimos, sempre que demonstramos a verdade ou o que parece ser a verdade [...]".

Reboul (2004, p. XIII), ao re- alizar uma retrospectiva histórica em seu livro "Introdução à Retórica", identifica duas correntes opostas e predominantes dentro do estudo da retórica. Uma que vê a retórica como a arte de argumentar, buscando referências na política e na filosofia, e outra que considera a retórica o estudo do estilo, particularmente das figuras de estilo ${ }^{1}$. Segundo Meyer (2007, p. 22), autor que também fez um breve histórico da arte retórica, a retórica aristotélica "[...] persuade um auditório pela força de seus argumentos, ou agrada a esse mesmo auditório pela beleza do estilo, que comove aqueles a quem se dirige." Isso demonstra que a retórica aristotélica segue se equilibrando em dois pilares: a argumentação e o estilo, unindo as duas correntes teóricas.

A retórica aristotélica possui uma função muito específica, identificada por Jean Voilquin e Jean Capelle (In ARISTÓTELES, [1972?], p. 22-23), ela visa a descobrir o que há de persuasivo em cada discurso, e não em produzir textos ou alterar comportamentos de quem os lê. Ou seja, aquele que tem por função redigir um discurso ou qualquer construção verbal persuasiva, como a propaganda, pouco uso fará da retórica, mas aquele que procura entender os meios pelos quais a persuasão se dá, este sim, será beneficiado por seu conhecimento.
1 Existem muitas denominações para as figuras: figuras de linguagem, de palavras, de harmonia, de morfologia, de construção, de concordância, de imagística, de pensamento, tropos, etc. Optou-se pelo uso do termo "figuras de estilo", em detrimento dos outros existentes por ser o que melhor engloba o vasto número de figuras, uma vez que o "figuras de linguagem" encontra-se muitas vezes relacionado somente às figuras de sintaxe, conforme Pires-deMello (2001). 


\section{A verossimilhança da linguagem publicitária}

Martins (1997, p. 33) diz que não existe uma linguagem estritamente publicitária, e sim técnicas linguísticas com uso mais frequente em anúncios e textos de propaganda. Isto é, com o tempo, o texto publicitário foi se adaptando ao que dava mais resultado, formando suas próprias características. São técnicas peculiares a ela, que "[...] influenciam o comportamento do possível consumidor pela argumentação e expressividade ${ }^{2}$ " (GONZALES, 2003 , p. 11). A linguagem publicitária possui apenas um objetivo, a persuasão, e todos os seus recursos são voltados somente para ele. Esta linguagem, mesmo possuindo esporadicamente características de outras, como a literária, transforma os elementos que emprestou e os reverte para seu objetivo predeterminado (LADEIRA, 1987). O objetivo, a persuasão de toda propaganda, é vender a mercadoria, mas para consegui-lo, é preciso que a mensagem vença alguns obstáculos, e o primeiro é ser notado pelo consumidor. E é principalmente para ser notada e lembrada, que a mensagem publicitária adquire certas características que formam sua linguagem própria. É preciso tornar familiar o que se está vendendo, aumentar sua banalidade, e, principalmente, diferenciá-lo dos outros.

A linguagem característica

2 "É o ato de representar ou comunicar por meio de formas lingüísticas impressões subjetivas, pensamentos, emoções e intenções" (MARTINS, 1997, p. 47). Também pode ser entendido como estilo. aparecer métodos e formas usuais nos textos de propaganda atuais. Para Citelli (1988, p. 43), o texto publicitário é resultado da conjunção de vários fatores psico-socio-econômicos e do uso de efeitos retóricos, entre eles as figuras de linguagem e as técnicas argumentativas, os dois principais pilares da retórica clássica.

Uma das premissas da retórica é persuadir a plateia de que sua causa é a mais verossímil (e não a absolutamente verdadeira), e isto também se aplica à propaganda: a mensagem publicitária possui um acordo pré-determinado com seu público, o chamado acordo prévio, citado por Reboul (2004). Presume-se que aquela mensagem tem o objetivo de persuadir quem a lê, e por isso a maioria do que é dito em propaganda não é tomado como verdade, ao contrário do que acontece com a mensagem jornalística. Por isso, para gerar a persuasão buscada, a mensagem publicitária deve fornecer ao seu interlocutor uma lógica interna capaz de convencer. Lógica esta que é fornecida pela combinação entre argumentos $\mathrm{e}$ estilo, pela retórica. "Persuadir não é apenas sinônimo de enganar, mas também o resultado de certa organização do discurso que o constitui como verdadeiro para o receptor" (CITELLI, 1988, p. 14).

Dentro da lógica fornecida pelo discurso publicitário, a mercadoria anunciada precisa, ao menos, parecer possuir valor de uso para que as pessoas o adquiram, segundo Vestergaard e Schrøder (1988, p. 7). O consumidor médio não se surpreende com o exagero da propaganda, pois a vida o acostumou a nun- 
ca alcançar o que se sonha. A mensagem publicitária, porém, preenche essa lacuna sentimental do receptor, alimenta sua fantasia e ele continua com um 'futuro continuamente adiado' (BERGER, 1972:146" apud IBIDEM, p. 132). Para isso, o anunciante deve utilizar-se da persuasão - e não apenas de informações concretas ou denotadas - para obter a verossimilhança pretendida. Barthes, um dos notórios retores modernos, (1975, p. 157) reconhece o papel da verossimilhança nas mensagens dos meios de comunicação de massa:

Quantos filmes, folhetos, reportagens comerciais, poderiam tomar como divisa a regra aristotélica: "Mais vale um verossimil impossivel, que um possivel inverossimil": mais vale relatar aquilo que o público julga possivel, mesmo que seja cientificamente impossivel, do que contar o que na realidade é possivel, se tal possivel é rejeitado pela cesura coletiva da opinião corrente (BARTHES, 1975, p. 157).

Para alcançar o objetivo de persuadir e fornecer uma mensagem lógica e verossímil ao receptor/leitor/consumidor, a mensagem publicitária precisa utilizar alguns recursos: "recursos argumentativos racionais, ou emocionais; recursos retóricos estilísticos ou estéticos" (MARTINS, 1997, p. 35). São esses elementos da linguagem publicitária, presentes no sistema retórico clássico, que fornecem força à ideia oferecida na publicidade, para no final obter a persuasão.

\section{O sistema retórico aristotélico na publicidade impressa}

O sistema retórico básico foi criado por Aristóteles, porém foi posteriormente lapidado por seus sucessores e consiste de quatro partes: Invenção (heurésis), Disposição (taxis), Elocução (lexis), Ação (hypocrisis) (Reboul, 2004). Este sistema servia como um manual de "Como montar seu discurso persuasivo" aos moldes da Grécia Antiga. A maioria dos textos persuasivos baseia-se nesse modelo, mesmo que esta semelhança não seja percebida por seu autor. A propaganda também utiliza bastante esse modelo, como será demonstrado a seguir.

\section{Invenção}

É o momento no qual o orador, ou redator publicitário, busca os argumentos e os meios de persuasão que se relacionem com o tema de seu discurso ou texto (REBOUL, 2004, p. 43). A invenção é a etapa da formação do discurso que consiste em uma coleta de informações, no sentido de inventário, e também a criação da estrutura, invenção propriamente dita, que envolve criatividade.

O redator de propaganda retira as informações que necessita para construir as argumentações do texto de propaganda de um documento fornecido pela agência: o briefing. A palavra briefing vem do inglês, do verbo to brief, que significa resumir, fazer a apresentação sumariada de alguma coisa. É um documento que carrega as informações necessárias a respeito da empresa anunciante 
e da campanha, por isso, a maioria dos argumentos que o publicitário utiliza vem dele (BERTOMEU, 2006). Na argumentação racional é utilizada a descrição das qualidades e utilidades do produto, as causas e consequências, os motivos e resultados do ter e não ter o produto, e a explicação da superioridade do produto. (GONZALES, 2003, p. 22). A outra parte dos argumentos, que normalmente compõe o fator criativo do anúncio, vem da vivência pessoal de cada publicitário (SANT'ANNA, 1998, p. 146). Zeca Martins, (2003, p. 29), considerando o lugar da busca das informações para a formulação de argumentos, diz que o escritor de propaganda, o redator, deve estar sempre cercado de informações, e que esteja preparado para organizar argumentos a respeito de qualquer assunto.

Como parte da invenção, deve-se optar por qual gênero convém melhor ao assunto tratado, que Aristóteles definiu como três: judiciário, deliberativo e epidíctico ${ }^{3}$. Cada discurso possui um público ao qual se destina, uma ação que este gera sobre o público, um tempo do qual fala, e uma finalidade, como mostrado no quadro abaixo.
O orador do discurso publicitário pode ser dividido em dois: o redator, que de fato escreve o texto, e o anunciante, que é a empresa que o assina e paga por ele, porém, é o redator que realiza este momento da invenção do discurso, procurando argumentos e definindo o gênero. Carrascoza (1999, p. 26) percebe uma preferência pelo gênero deliberativo no texto publicitário:

[...] pode-se afirmar que o gênero deliberativo é dominante na trama do texto publicitário, cujo intuito é aconselhar o público a julgar favoravelmente um produto/serviço ou uma marca, o que pode resultar numa ação ulterior de compra. Para isso, elogia-se o produto, louvam-se suas qualidades e seu fabricante, o que torna relevante também seu caráter epidítico.

\section{Etos, Patos e Logos}

Dentro dos argumentos que podem ser utilizados em um discurso, distinguem-se três: etos e patos, de ordem afetiva, e logos, de ordem racional (REBOUL, 2004).

Reboul (2004, p. 48) define o etos como "[...] o caráter que o orador deve assumir para inspi-
3 Também chamado de demonstrativo.

4 Quadro elaborado com base no Livro Primeiro da Arte Retórica de Aristóteles ([1972?]).

\begin{tabular}{|l|l|l|l|}
\hline & Deliberativo & Epidíctico & Judiciário $^{4}$ \\
\hline Ouvinte & Assembleia & Espectador & Juiz \\
\hline Ação & $\begin{array}{l}\text { Aconselha ou } \\
\text { desaconselha }\end{array}$ & Elogio ou censura & $\begin{array}{l}\text { Pleiteiam } \\
\text { acusação e defesa }\end{array}$ \\
\hline Tempo & Futuro & Presente & Passado \\
\hline Fim & $\begin{array}{l}\text { O útil ou o } \\
\text { prejudicial }\end{array}$ & Belo ou feio & Justo ou injusto \\
\hline
\end{tabular}


rar confiança no auditório, pois, sejam quais forem seus argumentos lógicos, eles nada obtêm sem essa confiança [...]". Pode também ser entendido como a 'simpatia' que o orador possui com sua plateia para que não duvidem de seus argumentos. $\mathrm{Na}$ propaganda, o etos pode ser caracterizado pelo anúncio, pelo produto, pela marca, ou mesmo por algum personagem presente na campanha. Um anúncio criativo, inteligente e adequado ao público persuade mais rápido, gera uma admiração em quem o recebe e este cede à argumentação da mensagem (BARRETO, 2004a, p. 136). Ser criativo, portanto, faz parte do etos de um anúncio de propaganda, pois, à medida que ser criativo o faz ter maior empatia com o público, ele se torna superior, cresce em autoridade e persuade mais facilmente.

Segundo Reboul (2004, p. 48), "O patos é o conjunto de emoções, paixões e sentimentos que o orador deve suscitar no auditório com seu discurso". O orador deve se adaptar aos diferentes públicos para se aproveitar de suas particularidades. $\mathrm{Na}$ publicidade, o patos é a preocupação constante com a adequação da mensagem ao público específico. E sendo a propaganda, no geral, voltada essencialmente para o auditório, o público-alvo, isso faz dela uma forma linguística voltada para o patos. Ser voltada para o público também significa que a mensagem deve ser retórica e agradável, sempre associada à poética de alguma forma para causar um bem estar em quem a recebe (MEYER, 2007, p. 102). Na propaganda, especialmente, além de causar bem estar no público, o objetivo é também chamar a atenção dele e causar memorização da mensagem. Conscientemente, o criador de propaganda deve buscar o maior grau de empatia possível com o receptor, e para isso ele deve antecipar-se aos seus desejos e 'conversar' com o consumidor à maneira que ele está acostumado.

O logos diz respeito aos argumentos racionais propriamente ditos, sendo eles indutivos ou dedutivos (REBOUL, 2004, p. 49). Constitui as argumentações racionais da mensagem, como as qualidades do produto, ou qualquer outro tipo de informação técnica, como o preço.

Em resumo, o etos (orador) do anúncio se apresenta ao auditório com sua autoridade e simpatia e em seguida expõe o logos (argumentos) do anunciante. O patos (emoções) atua sobre as emoções do consumidor, levando-o à conclusão (MEYER, 2007).

\section{Disposição}

É a ordenação dos argumentos que culminará, no plano do discurso, sua organização interna (REBOUL, 2004, p. 43). A disposição é formada por no mínimo quatro partes, sendo que alguns autores chegam a listar sete: exórdio, narração, confirmação, digressão e peroração. Carrascoza (1999), redator publicitário e estudioso da linguagem publicitária, considera o esquema aristotélico - a disposição em si - como uma das normas que molda o discurso publicitário e o diferencia do discurso 
jornalístico, no qual normalmente está inserido (anúncio entre matérias).

O exórdio é a parte inicial do discurso e tem como função principal introduzir o auditório ao assunto, despertar suas paixões (ARISTÓTELES, [1972?]), e torná-lo dócil, atento e benevolente (REBOUL, 2004). Em um anúncio de propaganda impressa, é representado pelo título do anúncio, que é o momento no qual se tenta chamar a atenção do leitor para o resto do anúncio, ou de logo de início passar a mensagem de uma forma resumida (CARRASCOZA, 1999). A narração é a exposição dos fatos propriamente dita e, se não for objetiva, deverá ao menos parecer sê-lo. "Para ser eficaz, [o texto] deve ter três qualidades: clareza, brevidade e credibilidade" (REBOUL, 2004, p. 56). Em um anúncio, a narração estaria na lista de atributos que um produto/serviço pode ter (CARRASCOZA, 1999). Em seguida, vem a comprovação da narração realizada, as provas do que foi dito, a confirmação, ou seja, as provas da explicação destes atributos (IBIDEM). É o momento do logos, do raciocínio, o que não exclui a utilização do patos e etos também. Para encerrar, o orador pode optar por uma digressão, uma mudança do assunto que incorre como um argumento, ou ir diretamente à peroração, o final do discurso. Na propaganda, a peroração acaba tendo um peso similar ao do exórdio, encerrando e resumindo o raciocínio do anúncio, normalmente num slogan (IBIDEM).

\section{Elocução}

Segundo Reboul (2004, p. 43), a elocução é o momento da escrita que diz respeito à redação propriamente dita, ao estilo de quem escreve. Tudo que for escrito deve ter a função única de persuadir, seja pela emoção ou pelo intelecto.

\section{Portanto, a retórica criou uma estética da prosa, uma estética puramente funcional, da qual tudo o que é inútil é excluido, em que o mínimo efeito de es- tilo se justifica pela exigência de persuadir, em que qualquer artifício gratuito engendra pre- ciosismo ou vulgaridade (IBI- DEM, p. 62).}

É interessante perceber como a linguagem retórica se aproxima da publicitária, ambas valorizando o sintetismo e a funcionalidade.

O discurso deve ser adaptado ao assunto (estilo), ao auditório (possuir clareza) e ao orador (empatia do orador com o auditório) (IBIDEM), para que ele tenha uma transmissão de ideias eficientes. $\mathrm{Na}$ propaganda não poderia ser diferente, a linguagem varia de acordo com o objetivo do anúncio, o anunciante, e, principalmente, o público-alvo.

\section{A argumentação: exemplo e entimema}

Um dos pilares da construção retórica é a argumentação, que se complementa pelo estilo. Alguns autores, como Michel Meyer, consideram a argumentação como um elemento mais próximo da dialética, sendo sepa- 
rado da retórica. Neste trabalho, a argumentação será considerada parte integrante da retórica, em união com o estilo.

Conforme Reboul (2004), a argumentação possui cinco características: é dirigida a um auditório, possui uma língua natural, suas premissas são verossímeis, a progressão depende do orador e suas conclusões são sempre contestáveis. Sendo assim, um anúncio publicitário sempre é caracterizado por uma argumentação, pois, cada auditório (público-alvo) é singular e possui variações de competência, crenças e emoções, por isso cada argumentação deve ser pensada para cada auditório, visando o fim da persuasão. A língua natural de uma argumentação é passível de ambiguidades e variações culturais, muitas vezes intraduzíveis, por isso, cada campanha deve ser adaptada para cada cultura e língua. As premissas são verossímeis quando parecem verdadeiras ao público-alvo, não existindo verdadeiro ou falso absoluto, a propaganda deve convencê-lo. A ordem pela qual os argumentos serão dispostos no discurso depende unicamente do orador que pode ser a marca, o personagem da peça publicitária ou mesmo o redator de propaganda. Por fim, a conclusão de uma argumentação é sempre um acordo entre os interlocutores, sendo ele amistoso ou não, o argumento mais forte deve impor-se sobre os outros por si só. Isto torna o resultado sempre contestável, já que o resultado pode variar a cada argumentação. O resultado esperado de uma argumentação de uma campanha publicitária, em geral é a mudança de atitude do público, que agora se encontra favorável à marca anunciada. Segundo Aristóteles ([1972?], Arte Retórica, I, II, III, 10, p. 37), existem somente duas estruturas argumentativas: o exemplo e o entimema: "Os discursos baseados em exemplos prestam-se mais que outros para persuadir; mas os discursos baseados em entimemas impressionam mais".

\section{Exemplo}

O exemplo possui uma forma indutiva, levando o raciocínio do fato à regra, do particular ao geral. Exemplo simples de um exemplo em propaganda: o cabelo da modelo fica sedoso e brilhoso quando utiliza o Xampu $\mathrm{X}$, logo, o cabelo da consumidora ficará também. Um detalhe que não se pode ver nesse raciocínio, é que o resultado da utilização do Xampu X varia de acordo com a estrutura do fio de cada mulher, logo, uma generalização desse porte corre um grande risco de rro. Um exemplo só pode ser realmente validado quando tratar de poucos casos, os quais podem ser todos verificados para depois ser tirada uma conclusão.

\section{Entimema}

O entimema é uma espécie de silogismo ${ }^{5}$ incompleto (pois falta a ele uma das duas premissas) e possui estrutura dedutiva, nas quais suas premissas são, na maioria, verossímeis. Porém, deve-se tomar cuidado: mesmo as premissas sendo verossímeis, não é certo que o resultado o será. Voltando ao exemplo do Xampu, um entimema inverossímil ou aparen-
5 Por definição: "Silogismo. [Do Gr. Syllogismós, 'argumento', pelo lat. Syllogismu.] S. m. Lóg. Dedução formal tal que, postas duas proposições, chamadas premissas, delas se tira uma terceira, nelas logicamente implicada, chamada conclusão [...]" (FERREIRA, 1996). 
6 Existem muitas denominações para as figuras: figuras de linguagem, de palavras, de harmonia, de morfologia, de construção, de concordância, de imagística, de pensamento, tropos, etc. Optou-se pelo uso do termo "figuras de estilo", em detrimento dos outros existentes por ser o que melhor engloba o vasto número de figuras, uma vez que o "figuras de linguagem" encontra-se muitas vezes relacionado somente às figuras de sintaxe, conforme Pires-deMello (2001). te: a atriz é bem-sucedida, a atriz usa o Xampu X, logo, quem usa o Xampu X é bem-sucedido. O raciocínio do entimema resulta em uma premissa inverossímil, que muitas vezes é utilizada falaciosamente em propaganda. $\mathrm{O}$ entimema também gera um prazer em quem o recebe, pois sua concisão passa a tarefa de completar o raciocínio para quem o recebe (BARTHES, 1975, p. 191).

\section{O estilo e as figuras de estilo ${ }^{6}$}

O estilo é um dos pilares básicos da retórica, acompanhado da argumentação. Como diz Aristóteles ([1972?], Arte Retórica, III, I, 2, p. 205): "[...] não basta possuir a matéria do discurso; urge necessàriamente (sic) exprimirse na forma convincente, o que é de suma importância para dar ao discurso uma aparência satisfatória". Para Aristóteles, o estilo é indispensável na formação de um discurso, pois sem ele não haveria persuasão, visto que cada elemento envolvido altera as variáveis que precisam ser consideradas, como: o auditório, o juiz, o tipo do discurso, o tempo verbal, entre outros. Neste caso, a aparência do discurso importa, pois a roupagem que os argumentos levam também contribui para a persuasão.

As figuras de estilo derivam do momento da elocução na formação do discurso, e algumas definições as colocam como um "desvio" do sentido ordinário de uma palavra ou expressão, como a de Aristóteles ([1972?], Arte Retórica, III, II, I, 2, p. 208): "Desviar uma palavra de seu sentido ordinário permite dar ao estilo maior dignidade". Segundo Meyer (2007), uma figura retórica é algo que diz que uma coisa é outra, sem sê-lo realmente. Em outras palavras, transfere o sentido de uma palavra para outra ao igualá-las, com isso, a figura concilia o contraditório. As figuras existem para gerar um prazer em quem as ouve, assim gerar maior lembrança. A figura é, portanto, uma fruição a mais, uma licença estilística para facilitar a aceitação do argumento (REBOUL, 2004, p. 114). Vê-se, então, que a argumentação dificilmente seria persuasiva sem o recurso do estilo.

Das muitas técnicas de persuasão identificadas por Brown (1971), em sua obra Técnicas de Persuasão, as figuras de estilo são as que podem ser mais obviamente aproximadas da Retórica Aristotélica, entre outras. Reboul (2004) divide as figuras de acordo com a parte da linguagem que ela desvia.

\section{Figuras de palavra}

São também chamadas de "Figuras de Dicção" por Piresde-Mello (2001), por dizerem respeito à parte fônica de um texto, à pronúncia e à estrutura das palavras. Sandmann (1993) destaca como figuras de palavra alguns aspectos fonológicos mais marcantes na linguagem publicitária e ressalta que o objetivo do uso deste tipo de estratégia linguística leva um prazer estético ao leitor, o que torna sua memorização mais fácil, levando o interlocutor à ação. Os aspectos morfológicos estão relacionados 
à palavra e sua estrutura, sendo os mais criativos (identificados pelo autor) a prefixação, a sufixação, e o cruzamento de palavras para criação de palavras novas. As figuras de palavra são as que criam mais jogos e brincadeiras com o texto publicitário, visando o objetivo de surpreender o leitor, chamando assim sua atenção (MARTINS, 2003, p. 45). Algumas das mais notadas na propaganda impressa são: Ritmo, Rima, Aliteração/Assonância/ Coliteração e Onomatopeia (PIRES-DE-MELLO, 2001; GONZALES, 2003, p. 124).

\section{Figuras de sentido}

São também chamadas de "Figuras de semântica" por Pires-de-Mello (2001), pois se referem à mudança de sentido das palavras ou expressões ao seu significado. Com relação aos aspectos semânticos, a duplicidade de sentidos é apontada como uma característica extremamente marcante da linguagem publicitária, sendo as mais citadas a polissemia e a homonímia. É interessante perceber que não foram encontradas na literatura específica de figuras estas duas figuras acima citadas. Contudo, a maioria das figuras listada possui, em algum grau, uma multiplicidade de sentido implícita.

Os vários sentidos existentes em uma só palavra ou expressão geram operações mentais no leitor, que tenta destrinchá-los, o que gera um alto grau de lembrança dessa mensagem. "Tratase de um resultado psicológico que poderá ficar no inconsciente e conduzir, em determinados momentos, a ações concretas, de aquisição do produto, ou de escolha" (MARTINS, 1997, p. 60)

Nesse mecanismo de vários sentidos em um só, as palavras plenas (substantivos, adjetivos e verbos) têm seu sentido ampliado pelo desenvolvimento do sentido figurado (conotado), junto ao literal (denotado). "Enquanto a denotação transmite a informação, a conotação permite uma abertura em leque do significado" (DE CARVALHO, 2002, p. 20).

Algumas figuras importantes para a propaganda: a Metáfora, a Comparação e a Metonímia. A metáfora, por ser facilmente encontrada na língua em várias situações, é uma das figuras mais utilizadas em publicidade. Consiste na transferência dos significados de uma palavra para outra (GONZALES, 2003, p. 104) (SANDMANN, 1993, p. 85). A comparação não é uma figura propriamente dita, mas sim uma forma de metáfora, apesar de ser citada como uma (GONZALES, 2003). A metonímia é semelhante à metáfora, porém tem sua base na contiguidade, na associação espacial ou histórica dos termos envolvidos.

\section{Figuras de construção}

São também chamadas de "Figuras de sintaxe" por Piresde-Mello (2001), pois vêm de alterações da maneira na qual a frase é construída por meio de subtrações, repetições ou permutações. Aspectos sintáticos, ou de construção, são aqueles relacionados às combinações entre as palavras, e são apontados como especialmente expressivos den- 
tro da linguagem da propaganda. O texto publicitário normalmente é simples, com a menor quantidade de conjunções possível; topicalizado, ou seja, com a palavra mais enfática da frase vindo primeiro; possui coordenações sem conectivos e possui paralelismos e simetrias entre orações (SANDMANN, 1993). A exploração do nível gramatical da língua pode trazer uma expressão original das ideias e chamar atenção para a mensagem. Alguns recursos explorados são a incidência de determinadas classes de palavras ou de determinadas construções sintáticas e a maneira de organizar as palavras no texto (GONZALES, 2003, p. 125). As figuras mais encontradas na propaganda impressa são o Anacoluto, o Paralelismo, e a Repetição, que na realidade desdobram-se em várias outras figuras, mas está presente na propaganda pela repetição de uma mesma palavra ou ideia, principalmente através de slogans e palavras-chave (PIRESDE-MELLO, 2001; MARTINS, 2003; GONZALES, 2003).

\section{Figuras de pensamento}

São também chamadas de "Figuras de Imagística" por Pires-de-Mello (2001), pois geram imagens mentais e muitas vezes não são desvios propriamente ditos, mas recursos de expressão. Independem do som, do sentido e da ordem das palavras, se referem à associação de ideias inusitadas ou artísticas. Representando as figuras de pensamento, Sandmann (1993) fala do jogo com a palavra, o trocadilho, cujo sentido só é completado no âmbito do pensamento do leitor, que relaciona os significantes com os significados, formando a significação, ou significações, no caso de uma polissemia. As mais percebidas são a Paranomásia ou Trocadilho, Antítese, Paradoxo, Prosopopéia ou Personificação, Hipérbole, Sinestesia, Ironia, Eufemismo e Acumulação (GONZALES, 2003; SANDMANN, 1993; PIRES-DE-MELLO, 2001; CITELLI, 1988).

\section{Ação}

Retornando ao sistema retórico, chega-se à última parte, a ação, que é o próprio ato de discursar, de falar. A ação tomou nova vida com o surgimento dos meios de comunicação de massa eletrônicos, como o rádio e a televisão. O discurso tem agora seu momento de ser falado e ouvido novamente, ao invés de ser somente escrito e lido. Não convém adentrar muito neste assunto, visto que este artigo visa somente à publicidade impressa, mas com certeza é um ponto a ser estudado mais a fundo.

\section{O problema da expressividade: Forma x Conteúdo}

Analisando a linguagem da propaganda por meio do sistema retórico aristotélico básico, vê-se uma dúvida que surge: de onde vem a expressividade/criatividade de um anúncio: de sua forma, ou de seu conteúdo? Alguns autores respondem sobre o assunto.

Carrascoza (1999), ao dizer que as figuras de estilo aumentam 
a expressividade, coloca-as no âmbito do estilo. Martins (1997) recomenda que cada redator tenha a preocupação de colocar o máximo de expressividade em cada parte do texto, dizendo que assim ele ganhará mais eficácia e informatividade. Barreto (2004, p. 202) diz:

Criatividade editorial está intimamente ligada ao campo argumentação \& debate. Um anúncio apoiado no título ou no texto é um anúncio que argumenta, fundamentalmente. É uma exposição partidária, uma peça de oratória enlatada, uma elegia com fins práticos, persuasivos. (BARRETO, 2004, p.202.)

Adiante, cita o ato de emocionar um público como o de ter alcançado a criatividade. Aparentemente Barreto cometeu uma pequena confusão, pois, a oratória está mais ligada ao estilo que à argumentação. Tendo isso, conclui-se que ele atribui à expressividade, representada em sua fala pela criatividade, o resultado de uma cadeia de argumentos.

Carrascoza (2004) distingue dois cânones publicitários baseados nessa dicotomia estiloargumentação: o apolíneo, que apresenta um viés racional, e o dionisíaco, que se apoia na emoção e no humor, cada um em um extremo. O apolíneo é caracterizado pela dissertação, pela deliberação e segue o esquema retórico aristotélico. Utiliza-se muito da associação de palavras como uma forma de manter a unidade textual. Neste tipo de texto, predomina "[...] a valorização prática (conforto, sabor etc.) e a crítica (relação custo/benefício, inovações/preço etc.)" (IBIDEM, p. 26). O consumidor precisa conhecer as qualidades do produto ou serviço para decidir a respeito da compra ou não compra.

O dionisíaco é caracterizado pela narração e pela predominância do discurso epidíctico, mas ainda assim possui uma orientação para o destinatário e para a persuasão. Ele costuma valorizar conceitos utópicos, como a vida, a aventura, e os lúdicos: os luxos e caprichos (IBIDEM, p. 57). É geralmente utilizado quando o público pretendido é um grupo de elite e quando cumpre um objetivo mais institucional, por seu caráter mais subjetivo. É mais utilizada a mescla de ambas as formas, na qual o anúncio utiliza algo de narrativo sem perder o formato normal de texto publicitário. Esses dois estilos podem ser relacionados à dicotomia já citada entre estilo e argumentação.

Bremond (1975, p. 42), que analisa as técnicas persuasivas do emissor/influenciador, identifica duas formas de modificar as disposições das pessoas por meio da influência. 1 - A forma intelectual: o influenciador - emissor - age sobre o conhecimento que o receptor possui a respeito do assunto, informando ou dissimulando uma informação. 2 - A forma afetiva: o influenciador tenta conduzir seu receptor a temer ou desejar uma realidade, com a esperança de satisfações ou o receio de insatisfações. "Esses dois tipos de influência podem ser identificados com dois caminhos da [invenção]: convencer (fidem facere) e comover (animos impellere)." (IBIDEM).

A forma é a parte da criação que mais abre possibilidades 
criativas. Por forma entende-se expressão, ou estilo, que é o que chama a atenção do consumidor para a mensagem que o anúncio carrega. "Por isso a criatividade incansável do propagandista ou publicitário na busca incessante de meios estilísticos que façam com que o leitor ou ouvinte preste atenção ao seu texto, chocandoo até se for necessário" (SANDMANN, 1993, p. 13). Para alcançar a expressividade, vale também utilizar de padrões de linguagem diferentes, que fujam do padrão, mexendo novamente na forma.

Considerando o que foi dito pelos diversos autores, pode-se fazer algumas relações. O conteúdo de um anúncio visa a racionalidade, para convencer o consumidor a comprar o que se está vendendo (o logos é o produto). Para tanto, utiliza o tom racional, argumentações através de exemplos e entimemas ${ }^{7}$ (argumentos) e normalmente possuem um texto longo. Porém, somente argumentos racionais não são persuasivos o suficiente para que o consumidor se proponha a consumir o produto anunciado ao invés de outro do concorrente. Então, é necessário mudar a forma de dizer o que se quer, é necessário expressividade. $\mathrm{O}$ tom emotivo é uma das possibilidades para alcançar a expressividade, utilizando-se de estilo na escrita e das figuras de estilo para chamar a atenção e facilitar a memorização, adaptando o discurso a cada auditório e gerando empatia no mesmo (etos). Isto pode ser descrito no esquema abaixo, no qual o ideal é o equilíbrio de ambas as formas.
7 O entimema é uma espécie de silogismo incompleto (pois falta a ele uma das duas premissas) e possui estrutura dedutiva, nas quais suas premissas são, na maioria, verossímeis (REBOUL, 2004).

\begin{tabular}{|c|c|c|}
\hline Forma (como) & $x$ & Conteúdo (o que) \\
\hline Expressividade & $x$ & Racionalidade \\
\hline Comover (animos impellere) & $x$ & Convencer (fidem facere) \\
\hline Influência afetiva & $x$ & Influência intelectual \\
\hline Tom emotivo & $x$ & Tom racional \\
\hline Estilo & $x$ & Argumentação \\
\hline Figuras & $x$ & Exemplos e entimemas \\
\hline Etos & $x$ & Logos \\
\hline Conotações & $x$ & Denotações \\
\hline Modelo dionisíaco & $x$ & Modelo apolíneo \\
\hline & $\begin{array}{l}\text { Ideal } \\
\text { Patos }\end{array}$ & \\
\hline
\end{tabular}


É importante considerar que nem sempre estas duas variáveis estarão juntas. Um texto elaborado expressivamente pode conter uma mensagem sem importância, e o mesmo para o contrário, uma mensagem importante pode estar veiculada através de um texto inexpressivo (PIRES-DEMELLO, 2001, p. 18).

\section{Conclusão}

A retórica é hoje uma estratégia discursiva bastante utilizada na formação da mensagem da comunicação persuasiva de massa, tanto no estilo, quanto na argumentação - baseada nos estudos realizados numa literatura especializada. Todas as etapas do esquema retórico estão presentes de alguma forma no texto publicitário (Invenção, Disposição,
Elocução, Ação). O texto publicitário é deliberativo, pois aconselha o leitor a seguir o que ele diz. As interações entre o Etos, o Patos e o Logos são essenciais para cativar o público, gerar uma imagem positiva do produto ou marca, e vender os argumentos necessários para a persuasão.

É importante que cada redator de propaganda conheça um pouco mais sobre a origem da persuasão nos textos que produz, mas dificilmente fará um uso concreto desse conhecimento no dia a dia do trabalho criativo, visto que a maioria dos trabalhos é feita de forma intuitiva. Mesmo não utilizando o sistema retórico com consciência, a maioria dos criativos bebe nessa fonte que a todos alimenta desde as origens da civilização ocidental moderna.

\section{Referências}

ARISTÓTELES. Arte Retórica e Arte Poética. Tradução de Antônio Pinto de Carvalho. Rio de Janeiro: Leão, [1972?]. 357 p.

BARRETO, Roberto Menna. Criatividade em Propaganda. 13. Ed. São Paulo: Summus, 2004a. 282 p.

BARTHES, Roland. A retórica antiga. In GENETTE, G; BREMOND, C.; COHEN, J; KUENTZ, P.; GRUPO $\mu$. Pesquisas de Retórica. Tradução de Leda Pinto Maíra Iruzun. Petrópolis: Vozes, 1975. p. 147 - 221.

BERTOMEU, João Vicente. Criação na Propaganda Impressa. 3. Ed. São Paulo: Thompson Learning, 2006. 125 p.

BREMOND, Claude. O papel do influenciador. In ; COHEN, J; GRUPO $\mu$; KUENTZ, P.; GENETTE, G. Pesquisas de Retórica. Tradução de Leda Pinto Maíra Iruzun. Petrópolis: Vozes, 1975. p. 41 - 54.

BROWN, J. A. C. Téenicas de persuasão: Da propaganda à lavagem cerebral. Tradução de Octavio Alves Velho. 2. Ed. Rio de Janeiro: Zahar Editores, 1971. 209 p.

CARRASCOZA, João Anzanello. A evolução do texto publicitário: a associação de palavras como elemento de sedução na publicidade. 
8. ed. São Paulo: Futura, 1999.185p.

CARRASCOZA, João Anzanello. Razão e Sensibilidade no Texto Publicitário. 2. ed. São Paulo: Futura, 2004. 207 p.

CITELLI, Adilson. Linguagem e Persuasão. 3. Ed. São Paulo: Ática, 1988. $77 \mathrm{p}$.

DE CARVAlHO, Nelly. Publicidade: A linguagem da sedução. 3. ed. São Paulo: Ática, 2002. 175p.

FERREIRA, Aurélio Buarque. Novo dicionário da Língua Portuguesa. 2. ed. rev. e aum. Rio de Janeiro: Nova Fronteira, 1996.

GONZALES, Lucilene. Linguagem Publicitária: análise e produção. São Paulo: Arte e Ciência, 2003. 151 p.

LADEIRA, Julieta de Godoy. Contato imediato com criação de propaganda. 2 ed. São Paulo: Global, 1987. 159 p.

MARTINS, Jorge S. Redação Publicitária: Teoria e prática. 2. ed. São Paulo: Ed. Atlas, 1997. 169 p.

MARTINS, Zeca. Redação publicitária: A prática na prática. São Paulo: Atlas, 2003. 177 p.

MEYER, Michel. A retórica. Tradução Marly N. Peres. São Paulo: Ática, 2007. $128 \mathrm{p}$.

PIRES-DE-MELLO, José Geraldo. Figuras de Estilo. 2. ed. São Paulo: Rideel; Brasília: UniCEUB, 2001. 142 p.

REBOUL, Olivier. Introdução à retórica. Tradução de Ivone Castilho Benedetti. São Paulo: Martins Fontes, 2004. 253 p.

ROMAN, Kenneth; MAAS, Jane. Como fazer sua propaganda funcionar. Tradução de Wladir Dupont. São Paulo: Nobel, 1994.

SANDMANN, Antônio. A Linguagem da Propaganda. São Paulo: Contexto, 1993.99 p.

SANT'ANNA, Armando. Propaganda: teoria, técnica e prática. 7. ed. rev. e at. São Paulo: Pioneira Thompson Learning, 2005. 469 p.

VESTERGAARD, Torben; SCHRØDER, Kim. A Linguagem da Propaganda. Tradução de João Alves dos Santos. São Paulo: Martins Fontes, 1988. 197 p. 